\title{
PENGARUH SISTEM OLAH TANAH DAN COVER CROP TERHADAP SIFAT FISIK TANAH DAN PERTUMBUHAN TANAMAN KARET
}

\author{
The Effect of Tillage and Cover Crop on Soil Physical Properties \\ and Young Rubber Plant Growth \\ Charlos Togi STEVANUS*, Risal ARDIKA, dan Jamin SAPUTRA \\ Balai Penelitian Sembawa, Pusat Penelitian Karet \\ Jalan Raya Palembang - Betung KM 29 PO BOX 112 \\ Palembang 30001 Sumatera Selatan \\ *Email : togie_stevanus@yahoo.co.id
}

Diterima : 22 Mei 2017 / Disetujui : 22 Februari 2018

\begin{abstract}
System of no-tillage and cover crop have been widely applied in several rubber plantations in Indonesia, but their impact on plant growth has not yet been known. This study was aimed to determine changes of soil physical properties and young rubber plant growth caused by tillage and cover crop. The research was conducted from November 2011 to Januari 2015 using a split plot experimental design with 2 faktors. The main plot was tillage system i.e. no-tillage (TOT) and conventional tillage (OT), while the subplot was type of cover crop i.e. without cover crop (TCC), Mucuna bracteata (MB), and weeds (GA). The observed parameters consisted of rubber plant growth and soil physical properties. The results showed that LCC system (MB and GA) change of soil aggregate, bulk density, and total soil porosity. At 26 months after planting rubber plants growth in MB and GA was significantly higher than that of control.
\end{abstract} $\begin{aligned} \text { Keyword : } & \text { Mucuna bracteata; no tillage } \\ & \text { system; rubber plant; Soil } \\ & \text { physical properties; weeding }\end{aligned}$

\begin{abstract}
Abstrak
Sistem tanpa olah tanah dan cover crop telah banyak diterapkan di beberapa perkebunan karet di Indonesia, namun pengaruhnya terhadap pertumbuhan tanaman belum diketahui. Penelitian ini bertujuan untuk mengetahui perubahan sifat fisik tanah dan pertumbuhan tanaman karet TBM akibat pengolahan lahan dan
\end{abstract}

penggunaan legume cover crop (LCC). Penelitian dilaksanakan pada bulan November 2011-Januari 2015 dengan menggunakan rancangan percobaan Split Plot dengan 2 faktor. Faktor utama adalah sistem olah tanah (tanpa olah tanah/TOT) dan olah tanah/OT), sedangkan anak petaknya yaitu jenis cover crop (tanpa cover crop/TCC), Mucuna bracteata/MB), dan gulma alami/GA). Pengamatan meliputi parameter pertumbuhan tanaman karet dan sifat fisik tanah. Hasil penelitian menunjukkan bahwa LCC (MB dan GA) mengubah agregat tanah, bobot isi, dan porositas total tanah. Pada umur 26 BST pertumbuhan tanaman karet pada perlakuan MB dan GA berbeda nyata dibandingkan kontrol.

Kata kunci : gulma; Mucuna bracteata; Sifat fisik tanah; tanaman karet; tanpa olah tanah

\section{PENDAHULUAN}

Sifat fisik tanah merupakan salah satu faktor yang menentukan perkembangan pertumbuhan tanaman. Busscher dan Bauer (2003) menunjukkan bahwa pertumbuhan akar tanaman meningkat seiring dengan penurunan kekerasan tanah. Stirzaker, Passiora, dan Wilms (1996) menyatakan bahwa penurunan bobot isi tanah melalui pembuatan lubang biopori mampu meningkatkan pertumbuhan tanaman melalui mekanisme peningkatan cadangan air dan hara Persiapan lahan untuk 
penanaman baru merupakan salah satu faktor yang dapat mempengaruhi sifat fisik tanah. Pada umumnya persiapan lahan pada perkebunan karet meliputi pengolahan tanah berupa pembajakan dan garu, kemudian dilanjutkan penanaman cover crop. Namun tidak semua perkebunan karet dapat menerapkan sistem persiapan lahan tersebut. Kegiatan tersebut dinilai memerlukan biaya yang mahal dan waktu pengolahan yang lama. Hal ini menyebabkan perkebunan yang memiliki modal dan tenaga kerja terbatas tidak melakukan sistem ini. Alternatif lain untuk persiapan lahan di perkebunan karet adalah menggunakan sistem tanpa olah tanah (notillage) dan cover crop.

Sistem tanpa olah tanah bermanfaat dalam menurunkan tingkat erosi di lahan (Oost et al., 2000; Paulenard et al., 2001). Rhoton, Shipotalo, Lindbo (2002) menyatakan bahwa erosi dapat ditekan melalui sistem tanpa olah tanah sebesar \pm 3,9 kali dibandingkan dengan olah tanah. Keuntungan lain penerapan sistem ini adalah meningkatkan kandungan karbon tanah (Miller \& Brinklemeyer, 2004).

Tanaman penutup tanah (cover crop) ditanam untuk melindungi tanah dari ancaman erosi serta memperbaiki sifat kimia dan fisik tanah. Tanaman ini berfungsi untuk menahan dan mengurangi daya rusak butir-butir hujan dan aliran permukaan, sumber bahan organik, dan untuk mengurangi penyiangan yang intensif. Jenis tanaman penutup tanah yang telah banyak diaplikasikan di perkebunan karet adalah Mucuna bracteata (Mb) yang diintroduksi dari India. Keuntungan yang diperoleh dari kacangan penutup tanah pada perkebunan karet adalah penambahan bahan organik yang tinggi dan fiksasi $\mathrm{N}$ yang dapat meningkatkan kesuburan tanah dan produksi tanaman karet.

Studi mengenai perubahan sifat fisik tanah akibat adanya sistem olah tanah dan penanaman cover crop di perkebunan karet masih sedikit. Tujuan penelitian ini antara lain a) mengetahui perubahan sifat fisik lahan akibat pengaruh sistem olah tanah dan cover crop di perkebunan karet dan b) mengevaluasi pengaruh sistem olah dan cover crop terhadap pertumbuhan tanaman karet belum menghasilkan.

\section{BAHAN DAN METODE}

Penelitian dilaksanakan di Kebun Percobaan Balai Penelitian Sembawa, Kabupaten Banyuasin, Provinsi Sumatera Selatan, pada bulan November 2011 Januari 2015. Penanaman tanaman karet dilakukan pada bulan Desember 2011. Pengujian sifat fisika tanah dilakukan di Laboratorium Fisika Tanah, Departemen Ilmu Tanah dan Sumberdaya Lahan, Institut Pertanian Bogor.

Rancangan penelitian yang digunakan adalah split plot yang terdiri dari 2 faktor dan 4 ulangan dengan luas tiap plot berukuran 0,25 Ha. Petak utama adalah sistem olah tanah yang terdiri atas : (1) olah tanah sempurna (OT) dan (2) tanpa olah tanah (TOT), sedangkan anak petak adalah Jenis cover crop yang terdiri atas : (1) tanpa cover crop; (2) Mucuna bracteata (MB), dan (3) gulma alami/rumput alami (GA). Jarak tanam di penelitian ini adalah $6 \mathrm{~m} \times 3 \mathrm{~m}$ dengan menggunakan klon PB 260.

Pada perlakuan olah tanah sempurna, tunggul bekas tanaman karet dicabut dan dirumpuk secara stacking. Pengolahan tanah dilaksanakan dengan sistem bajak dan garu sebanyak 2 kali dengan kedalaman $40 \mathrm{~cm}$. Sementara itu, pada perlakuan tanpa olah tanah, tunggul bekas tanaman karet dicabut dan dirumpuk secara stacking namun tidak dilakukan bajak dan garu.

Untuk perlakuan jenis legume cover crop, dilakukan penanaman LCC Mucuna bracteata yang berasal dari India sejumlah 1 baris di gawangan karet dengan jarak 3-4 meter. Pembibitan Mucuna bracteata dilakukan dipolibeg berukuran $10 \mathrm{~cm} \mathrm{x} 15$ $\mathrm{cm}$, dan setelah itu dilakukan penanaman di lahan. Perlakuan tanpa vegetasi dilakukan pemberantasan gulma secara penuh pada plot percobaan (clean weeding), sedangkan perlakuan gulma alami/rumput alami dilakukan pemeliharaan gulma/rumput alami dengan sistem strip ada areal percobaan. Populasi setiap ulangan terdiri dari 50 pohon. 


\section{Cara Pengambilan Contoh Tanah}

Pengambilan sampel tanah dilakukan pada bulan Desember 2014 atau 33 bulan setelah tanam (33 BST). Contoh tanah utuh diambil pada kedalaman 0-20 $\mathrm{cm}$ dengan empat kali ulangan pada setiap perlakuan. Pengambilan contoh tanah dilakukan di antara gawangan dengan menggunakan tabung berbahan stainless dengan tinggi $7 \mathrm{~cm}$ dan diameter $5,5 \mathrm{~cm}$. Jumlah sampel yang diambil adalah 1 sampel/perlakuan. Jenis tanah pada penelitian ini adalah Typic Tropoudult, dengan persentase fraksi adalah $37 \%$ liat, $29 \%$ pasir, dan $34 \%$ debu.

\section{Curah Hujan Selama Penelitian (2012 - 2014)}

Data curah hujan selama penelitian (2012 - 2014) disajikan pada Tabel 1. Tabel tersebut menunjukkan bahwa tidak terjadi pengaruh EL Nino selama penelitian berlangsung.

Tabel 1. Curah hujan tahun 2012-2014 pada daerah penelitian

Table 1. Rainfall of 2012-2014 in research area

\begin{tabular}{lrrr}
\hline \multirow{2}{*}{$\begin{array}{l}\text { Bulan } \\
\text { Month }\end{array}$} & \multicolumn{3}{c}{$\begin{array}{c}\text { Curah hujan } \\
\text { Rainfall } \\
(\mathrm{mm})\end{array}$} \\
\cline { 2 - 4 } & 2012 & 2013 & 2014 \\
\hline Januari & 374,4 & 266,6 & 162 \\
Februari & 368 & 532,8 & 43 \\
Maret & 228 & 414,8 & 120 \\
April & 474,6 & 294 & 253,2 \\
Mei & 335,2 & 203,2 & 70,4 \\
Juni & 145 & 130,6 & 87,2 \\
Juli & 41,4 & 155,2 & 127,4 \\
Agustus & 52,4 & 203,4 & 135 \\
September & 46,8 & 175,6 & 12,8 \\
Oktober & 223,6 & 201,4 & 37,4 \\
November & 332,8 & 260,6 & 309,4 \\
Desember & 315,6 & 612,8 & 493,6 \\
\hline Total & $\mathbf{2 . 9 3 7 , 8}$ & $\mathbf{3 . 4 5 1 , 0}$ & $\mathbf{1 . 8 5 1 , 4}$ \\
\hline
\end{tabular}

\section{Pengamatan Penelitian :}

Pengamatan yang dilakukan terdiri atas :

(1) Parameter pertumbuhan tanaman. Analisis pertumbuhan tanaman dilakukan dengan mengukur lilit batang tanaman karet pada setiap perlakuan. Jumlah tanaman yang diamati adalah 25 tanaman dengan ketinggian pengukuran lilit batang sekitar 1 meter dari pertautan okulasi.

(2) Parameter sifat fisik tanah. Pengamatan sifat fisik lahan pada penelitian ini antara lain indeks kemantapan agregat (\%), bobot isi (\%), porositas (\%), kurva $\mathrm{pF}$ $1 ; 2 ; 2,54$; dan 4,2 (\% volume), dan distribusi pori drainase (\% volume).
Bobot isi : penetapan bobot isi diukur dengan perbandingan antara berat tanah kering dengan volume tanah.

Indeks kemantapan agregat : Penetapan agregat dilakukan dengan menggunakan metode pengayakan kering dan basah. Penetapan distribusi ukuran agregat menggunakan ayakan berukuran 8 $\mathrm{mm} ; 4,76 \mathrm{~mm} ; 2,83 \mathrm{~mm}$; dan $2 \mathrm{~mm}$. Selanjutnya masing-masing agregat dikelompokkan berdasarkan ukurannya dan ditentukan diameter massa rata-rata (DMR) dengan rumus: 
$\mathrm{DMR}=\sum_{\mathrm{i}=1}^{\mathrm{n}} \mathrm{Xi} \mathrm{Wi}$

Dimana (Remaks) :

$\mathrm{DMR}=$ Diameter massa rata-rata

$\mathrm{Xi} \quad=$ rata-rata ukuran agregat

$\mathrm{Wi}=$ massa agregat dengan ukuran tertentu.

Selisih antara rata-rata berat diameter agregat tanah pada pengayakan kering dan pengayakan basah merupakan indeks instabilitas, sehingga untuk mendapatkan indeks stabilitas menggunakan rumus :

Indeks stabilitas $=$

$$
\overline{\text { Indeks Instabilitas }}
$$

Penetapan porositas tanah : Porositas total tanah dihitung berdasarkan data bobot isi dan bobot jenis partikel tanah dengan rumus:

$1-\frac{\text { Bobot isi }}{\text { Bobot jenis partikel }} \times 100 \%$

Dimana bobot isi merupakan bobot kering suatu unit volume tanah dalam keadaan utuh, yang dinyatakan dalam $\mathrm{g} / \mathrm{cm}^{3}$. Sementara itu, bobot jenis partikel yang digunakan adalah rata-rata bobot jenis partikel tanah mineral pada umumnya yaitu $2,65 \mathrm{~g} / \mathrm{cm}^{3}$.

Kurva $\mathrm{pF}$ : Penetapan kurva $\mathrm{pF}$ dilakukan dengan menggunakan "Pressure Plate Apparatus" dengan tekanan $\mathrm{pF} 1$ (tekanan $10 \mathrm{~cm}$ air), pF 2 (tekanan $100 \mathrm{~cm}$ air), $\mathrm{pF} 2,54$ (tekanan 1/3 atm) dan $\mathrm{pF} 4,2$ (tekanan 15 atm). Kadar air \% volume dihitung berdasarkan perkalian antara contoh berat tanah tiap $\mathrm{pF}$ dengan bobot isi.

Distribusi ukuran pori drainase dapat dikelompokkan dalam 2 kelompok, yaitu :

1. Pori drainase makro: berdiameter lebih dari 300 mikro meter, bagian pori yang akan kosong tidak terisi pada $\mathrm{pF} 1,0$

2. Pori drainase mikro: berdiameter antara 30 sampai 9 mikro meter, bagian pori yang akan kosong tidak terisi air pada $\mathrm{pF}$ 2,0 sampai 2,54 .
(3) Pertumbuhan legume cover crop dan gulma pada perlakuan tanpa dan olah tanah. Sebagai tambahan data dan informasi, pertumbuhan bobot kering LCC dan gulma pada perlakuan tanpa dan olah tanah juga dilakukan pada penelitian ini. Pengukuran dilakukan pada 24 BST dengan menggunakan petak contoh berupa bujur sangkar di antara gawangan tanaman karet dengan ukuran $100 \mathrm{~cm}$ x $100 \mathrm{~cm}$.

\section{HASIL DAN PEMBAHASAN}

\section{Bobot Isi dan Kemantapan Agregat}

Data bobot isi dan kemantapan agregat pada umur 33 bulan setelah tanam (Tabel 2) menunjukkan bahwa tidak ada interaksi antara olah tanah dan penggunaan cover crop terhadap bobot isi dan kemantapan agregat. Pengolahan tanah tidak mempengaruhi indeks kemantapan agregat. Grant dan Lafond (1993) memperlihatkan hasil yang tidak berbeda nyata pada bobot isi di kedalaman $5 \mathrm{~cm}$ antara tanpa olah tanah dengan olah tanah minimum pada 3 sistem rotasi tanaman gandum. Hasil ini berbeda dengan penelitian yang ditunjukkan oleh Luttrel, (1963); Plante \& McGill (2002); dan Osunbitan et al. (2005) yang menyatakan bahwa teknik dan peningkatan frekuensi pengolahan tanah memberikan pengaruh dalam menurunkan kemantapan agregat dan bobot isi. Hasil serupa dengan penelitian ini dikemukakan oleh Fohrer, Berkenhagen, Hecker, dan Rudolph (1999) menyatakan bahwa hujan dengan intensitas yang tinggi dapat memecah kemantapan agregat menjadi microagregat sehingga terjadi penyumbatan pori tanah. Penyumbatan ini menyebabkan peningkatan nilai bobot isi pada perlakuan OT. Dalam penelitian ini terjadi hujan dengan intensitas tinggi yaitu 1851-3451 $\mathrm{mm} /$ tahun, sehingga hujan meningkatkan bobot isi pada perlakuan OT.

Perlakuan MB dan GA berbeda nyata dalam meningkatkan kemantapan agregat dan menurunkan bobot isi tanah dibandingkan TCC (Tabel 2). Akar tanaman cover crop akan mengeluarkan senyawa organik yang berfungsi sebagai perekat partikel-partikel tanah yang dapat meningkatkan kemantapan agregat tanah 
(Bronick \& Lal, 2005). Selain itu, legume cover crop akan mengeluarkan eksudat polysaccharides dan digunakan oleh koloni mikoriza yang terdapat di daerah perakaran untuk membentuk protein yang disebut dengan glomalin. Glomalin berperan penting dalam meningkatkan stabilitas agregat dan struktur tanah (Horman, 2009). Kondisi ini menyebabkan kemantapan agregat pada MB mempunyai nilai lebih tinggi dibandingkan perlakuan GA dan TCC. Hasil penelitian ini sama seperti yang dilaporkan Haynes dan Beare (1997), bahwa agregat tanah pada tanaman legume akan meningkat dibandingkan dengan tanaman non legume akibat adanya aktivitas mikroba yang tinggi pada daerah perakaran legume. Selain akar tanaman cover crop, tekstur dominan liat (37 \%) juga ikut menjadi agen "coating" dalam merekatkan partikelpartikel tanah. Kondisi ini menyebabkan tanah tidak mudah terdispersi sehingga meningkatkan nilai kemantapan agregat (Attou et al., 1998).

\section{Porositas Total Tanah dan Distribusi Ukuran Pori Tanah}

Tidak ada pengaruh interaksi antara perlakuan sistem olah tanah dan penggunaan cover crop terhadap porositas total tanah dan distribusi ukuran pori tanah. Pengolahan tanah tidak berpengaruh terhadap porositas tanah, persentase distribusi pori makro dan mikro (Tabel 3).
Tidak berpengaruhnya antar perlakuan ini juga dapat dijelaskan karena intensitas hujan yang tinggi selama penelitian, yaitu berkisar 2.938-3.451 mm/tahun. Seperti yang dijelaskan sebelumnya, intensitas hujan yang tinggi dapat memecah agregat menjadi mikroagregat sehingga persentase pori mikro pada perlakuan OT lebih besar dibandingkan dengan pori makro (Tabel 3). Selain itu, intensitas hujan juga dapat menyebabkan penyumbatan ruang kapilar pada pori antar agregat terutama pada perlakuan OT. Hal ini dapat menyebabkan perlakuan OT tidak berpengaruh terhadap porositas tanah dan distribusi ukuran pori tanah.

Persentase porositas total tanah pada perlakuan MB dan GA lebih besar daripada perlakuan TCC (Tabel 3). Keberadaan LCC dan gulma meningkatkan porositas total tanah dibandingkan dengan tanpa cover crop. Akan tetapi, persentase pori mikro dan makro tidak berbeda nyata dengan adanya cover crop. Menurut Cammeraat, Beek, dan Kooijman (2005), jenis perakaran vegetasi ikut mempengaruhi beberapa sifat fisik tanah, di antaranya pembentukan pori mikro dan makro di dalam tanah. Vegetasi dengan jenis perakaran tunggang akan lebih berpengaruh terhadap pori mikro dan makro dibandingkan dengan vegetasi perakaran serabut. Mucuna brateata dan gulma alami merupakan vegetasi dengan jenis perakaran serabut sehingga kemungkinan ini menjadi

Tabel 2. Pengaruh sistem olah tanah dan penggunaan cover crop terhadap bobot isi dan kemantapan agregat

Table 2. Effect of tillage system and the use of cover crop on bulk density and aggregate stability

\begin{tabular}{cccc}
\hline \multicolumn{2}{c}{$\begin{array}{c}\text { Perlakuan } \\
\text { Trearment }\end{array}$} & $\begin{array}{c}\text { Indeks kemantapan agregat } \\
\text { Soil agregate index } \\
(\%)\end{array}$ & $\begin{array}{c}\text { Bobot isi } \\
\text { Bulk density } \\
\left(\mathrm{g} / \mathrm{cm}^{3}\right)\end{array}$ \\
\hline Petak utama & TOT & $63,30 \mathrm{th}$ & $1,25 \mathrm{tn}$ \\
Main plot & OT & 62,26 & 1,24 \\
\hline Anak petak & TCC & $58,37 \mathrm{a}$ & $1,32 \mathrm{a}$ \\
Sub plot & MB & $65,78 \mathrm{~b}$ & $1,22 \mathrm{~b}$ \\
& GA & $64,18 \mathrm{~b}$ & $1,21 \mathrm{~b}$ \\
\hline
\end{tabular}

Keterangan : - Angka yang diikuti oleh huruf yang sama pada kolom dan petak yang sama, tidak berbeda nyata pada taraf uji 0,05

- tn : tidak nyata; TOT : Tanpa olah tanah; OT : Olah tanah; MB : Mucuna bracteata; GA : Gulma alami; TCC : Tanpa cover crop

Note: - Means followed by the same letter(s) in the same of column and plot were not significantly different at $5 \%$ level.

- tn : not different; TOT : No-tillage; OT : conventional tillage; ; MB : Mucuna bracteata; GA : weeds; TCC : Without cover crop. 
Tabel 3. Pengaruh sistem olah tanah dan penggunaan cover crop terhadap porositas total tanah dan distribusi pori drainase

Table 3. Effect of tillage system and the use of cover crop on soil total porosity and distribution of drainage pore

\begin{tabular}{|c|c|c|c|c|}
\hline \multirow{2}{*}{\multicolumn{2}{|c|}{$\begin{array}{l}\text { Perlakuan } \\
\text { Treatment }\end{array}$}} & \multirow{2}{*}{$\begin{array}{c}\text { Porositas total tanah } \\
\text { Total soil Porosity } \\
(\%)\end{array}$} & \multicolumn{2}{|c|}{$\begin{array}{l}\text { Pori drainase } \\
\text { Drainage pore }\end{array}$} \\
\hline & & & \multirow{2}{*}{$\begin{array}{c}\text { Mikro } \\
\text { micro pore } \\
(\%)\end{array}$} & $\begin{array}{c}\text { Makro } \\
\text { macro pore } \\
(\%)\end{array}$ \\
\hline Petak utama & TOT & 52,86 tn & & 7,93 tn \\
\hline Main plot & OT & 53,10 & 7,39 & 7,11 \\
\hline Anak petak & TCC & 50,33 a & 7,05 tn & 6,37 tn \\
\hline \multirow[t]{2}{*}{ Sub plot } & MB & $54,49 \mathrm{~b}$ & 8,41 & 8,02 \\
\hline & GA & $54,12 b$ & 6,77 & 8,18 \\
\hline
\end{tabular}

Keterangan : - Angka yang diikuti oleh huruf yang sama pada kolom dan petak yang sama, tidak berbeda nyata pada taraf uji 0,05

- tn : tidak nyata; TOT : Tanpa olah tanah; OT : Olah tanah; MB : Mucuna bracteata; GA : Gulma alami; TCC : Tanpa cover crop

Note: - Means followed by the same letter(s) in the same of column and plot were not significantly different at $5 \%$ level.

- tn : not different; TOT : No-tillage; OT : Conventional tillage; ; MB : Mucuna bracteata; GA : weeds; TCC : Without cover crop.

salah satu faktor mengapa cover crop tidak berpengaruh terhadap pori mikro dan makro. Akan tetapi, teori tersebut membutuhkan pengamatan dan penelitian lebih lanjut.

\section{Retensi Air Tanah}

Gambar 1 dan 2 menunjukkan bahwa pengolahan tanah dan vegetasi menggeser kurva retensi air tanah pada perkebunan karet namun tidak berpengaruh terhadap kadar air $\mathrm{pF} 1 ; 2$; 2,54; dan 4,2. Perlakuan pengolahan tanah maupun LCC juga tidak mempengaruhi air tersedia bagi tanaman (Tabel 4). Salah satu faktor yang berpengaruh terhadap kadar air $\mathrm{pF}$ dan air tersedia adalah distribusi ukuran pori tanah (pori mikro dan makro). Pori mikro merupakan jenis pori dengan diameter antara 30 sampai 9 mikro-meter, bagian pori yang akan kosong tidak terisi air pada $\mathrm{pF}$ antara 2 sampai 2,54. Sedangkan pori makro adalah pori dengan diameter lebih dari 300 mikro-meter, bagian pori yang akan kosong tidak terisi air pada $\mathrm{pF} 1$ (Rouquerol et al., 1994). Persentase pori mikro dan makro baik pada perlakuan olah tanah maupun jenis LCC menunjukkan tidak ada pengaruh nyata antar perlakuan.
Kondisi ini juga ikut menyebabkan perlakuan olah tanah dan LCC tidak berpengaruh nyata terhadap perubahan kurva retensi air dan air tersedia bagi tanaman.

\section{Pertumbuhan Tanaman Karet Belum Menghasilkan}

Pertumbuhan tanaman karet belum menghasilkan pada perlakuan dengan atau tanpa olah tanah menunjukkan berbeda nyata pada bulan ke-6 setelah tanam (BST), namun pada bulan berikutnya menunjukkan hasil tidak berbeda nyata (Tabel 4). Hal ini menunjukkan bahwa perlakuan pada penelitian ini belum berpengaruh terhadap pertumbuhan tanaman. Faktor pertumbuhan tanaman masih didominasi pada kondisi awal bibit tanaman karet. Pada perlakuan vegetasi di antara gawangan karet, pertumbuhan tanaman karet belum menghasilkan dari bulan ke-6 sampai ke-20 tidak menunjukkan perbedaan nyata, namun berbeda nyata pada bulan ke-26 (Tabel 5). Pertumbuhan tertinggi pada 26 BST ditunjukkan pada vegetasi GA, kemudian diikuti oleh MB dan TCC. Hal ini disebabkan 


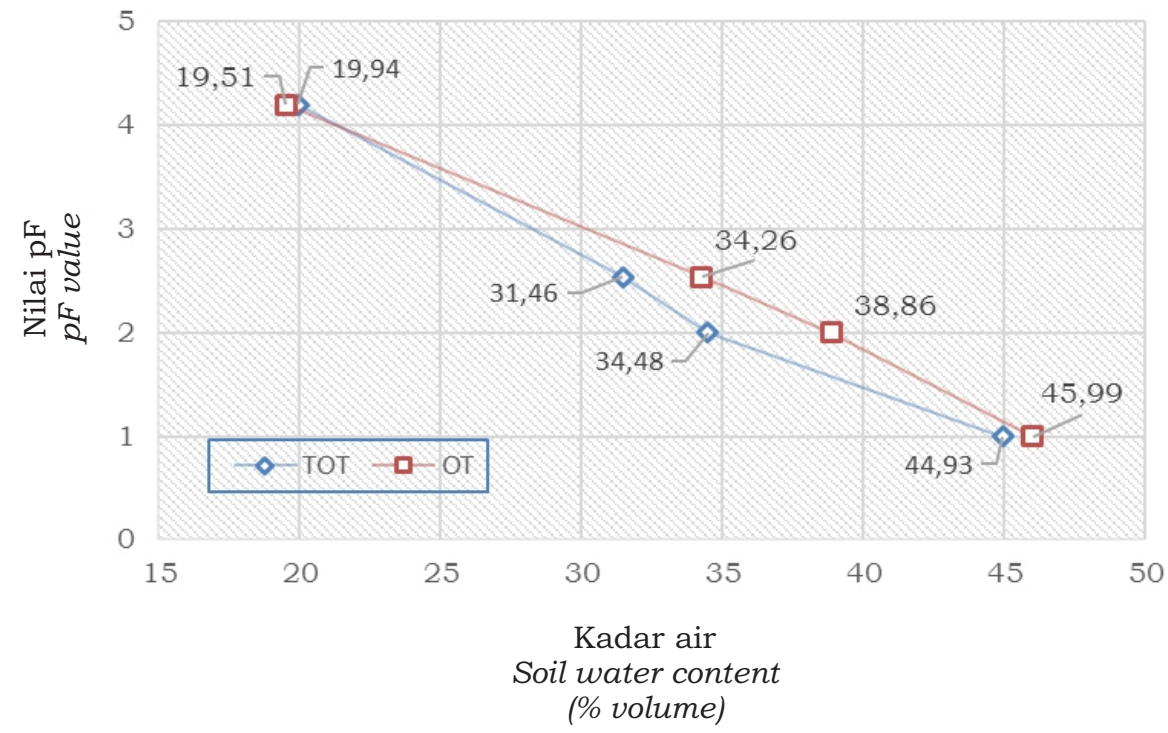

Gambar 1. Kurva retensi air pada perlakuan OT dan TOT Figure 1. The curve of water retention in OT and TOT treatment

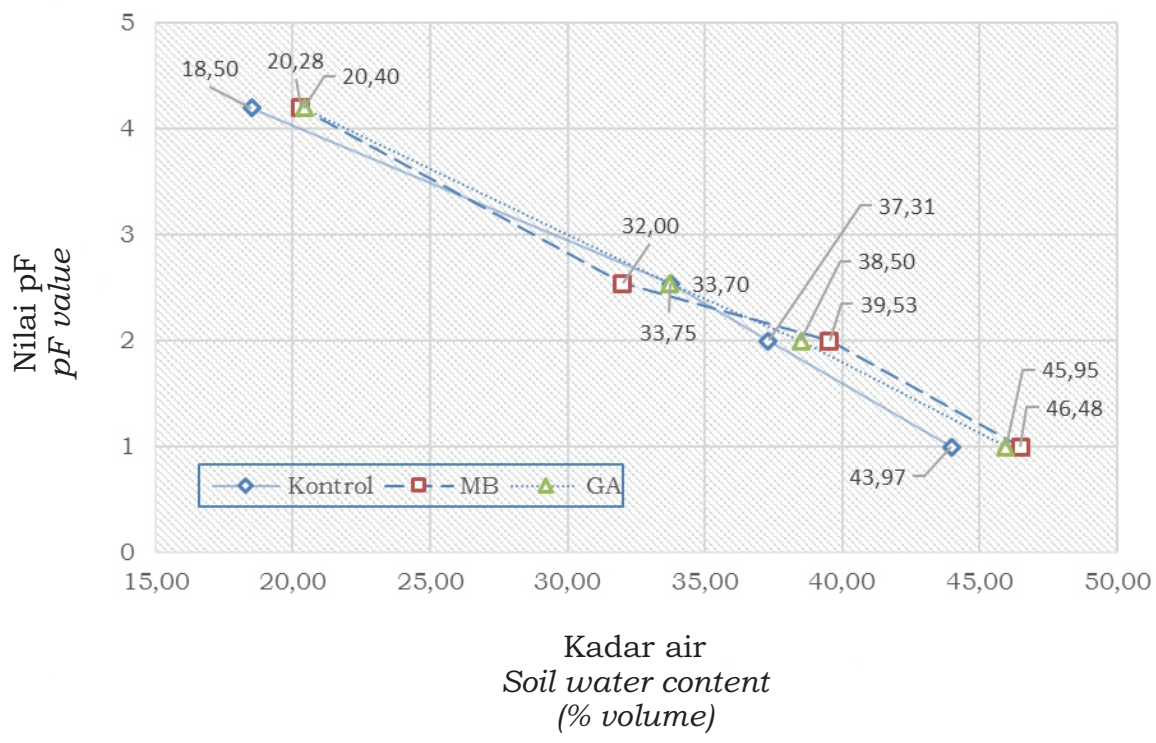

Gambar 2. Kurva retensi air pada perlakuan TCC, MB dan GA Figure 2. The curve of water retention in TCC, MB and GA treatment 
Tabel 4. Pengaruh pengolahan tanah dan penggunaan LCC terhadap persentase kadar air tersedia

Table 4. Effect of soil tillage and the use of cover crop on percentage of available water content

\begin{tabular}{cclll}
\hline \multirow{2}{*}{$\begin{array}{c}\text { Perlakuan } \\
\text { Treatment }\end{array}$} & \multicolumn{3}{c}{$\begin{array}{c}\text { Kadar air } \\
\text { Soil water content } \\
\text { (\% volume) }\end{array}$} \\
\cline { 2 - 5 } & & \multicolumn{1}{c}{$\mathrm{pF} \mathrm{2,54}$ A 4,2} & \multicolumn{1}{c}{ Air tersedia } \\
\hline Petak utama & TOT & $31,46 \mathrm{tn}$ & $19,94 \mathrm{tn}$ & $11,97 \mathrm{tn}$ \\
Main plot & OT & 34,26 & 19,51 & 11,67 \\
& & & $18,50 \mathrm{tn}$ & $12,34 \mathrm{tn}$ \\
Anak petak & TCC & $33,75 \mathrm{tn}$ & 20,28 & 11,77 \\
Sub plot & MB & 31,12 & 20,40 & 11,34 \\
& GA & 33,70 & &
\end{tabular}

Keterangan : - Angka yang diikuti oleh huruf yang sama pada kolom dan petak yang sama, tidak berbeda nyata pada taraf uji 0,05

- tn : tidak nyata; TOT : Tanpa olah tanah; OT : Olah tanah; MB : Mucuna bracteata; GA : Gulma alami; TCC : Tanpa cover crop

Note: - Means followed by the same letter(s) in the same of column and plot are not significantly different at $5 \%$ level.

- tn : not different; TOT : No-tillage; OT : Conventional tillage; ; MB : Mucuna bracteata; GA : Weeds; TCC: Without cover crop.

Tabel 5. Pengaruh pengolahan tanah dan penggunaan LCC terhadap pertumbuhan tanaman karet belum menghasilkan

Table 5. Effect of soil tillage and the use of cover crop on immature rubber plant growth

\begin{tabular}{|c|c|c|c|c|c|}
\hline \multirow{2}{*}{\multicolumn{3}{|c|}{$\begin{array}{l}\text { Perlakuan } \\
\text { Treatment }\end{array}$}} & \multicolumn{3}{|c|}{$\begin{array}{l}\text { Lilit batang } \\
\text { Girth } \\
(\mathrm{cm}) \\
\end{array}$} \\
\hline & & & $6 \mathrm{BST}$ & $20 \mathrm{BST}$ & $26 \mathrm{BST}$ \\
\hline \multirow{2}{*}{\multicolumn{2}{|c|}{$\begin{array}{l}\text { Petak utama } \\
\text { Main plot }\end{array}$}} & TOT & $6,50 \mathrm{a}$ & $12,34 \mathrm{tn}$ & 19,84 tn \\
\hline & & OT & $4,94 \mathrm{~b}$ & 12,41 & 19,52 \\
\hline \multirow{3}{*}{\multicolumn{2}{|c|}{$\begin{array}{c}\text { Anak petak } \\
\text { Sub plot }\end{array}$}} & TCC & $5,71 \mathrm{tn}$ & $12,10 \mathrm{tn}$ & $17,81 \mathrm{a}$ \\
\hline & & MB & 5,69 & 12,56 & $20,10 \mathrm{~b}$ \\
\hline & & GA & 5,78 & 12,47 & $21,12 \mathrm{~b}$ \\
\hline \multicolumn{6}{|c|}{$\begin{array}{l}\text { Keterangan : - Angka yang diikuti oleh huruf yang sama pada kolom dan petak yang sama, tidak } \\
\text { berbeda nyata pada taraf uji 0,05 } \\
\text { - tn : tidak nyata; TOT : Tanpa olah tanah; OT : Olah tanah; MB : Mucuna bracteata; GA : } \\
\text { Gulma alami; TCC : Tanpa cover crop } \\
\text { Note: } \\
\text { - Means followed by the same letter(s) in the same of column and plot are not significantly different } \\
\text { at } 5 \% \text { level. } \\
\text { - th : not different; TOT : No-tillage; OT : Conventional tillage; ; MB : Mucuna bracteata; GA : } \\
\text { Weeds; TCC: Without cover crop. }\end{array}$} \\
\hline
\end{tabular}

adanya perbaikan sifat fisik tanah yaitu peningkatan kemantapan agregat, porositas total tanah, dan penurunan bobot isi dengan adanya keberadaan vegetasi.

Pertumbuhan tanaman selain ditentukan oleh sifat fisik tanah, juga dipengaruhi oleh iklim. Hasil penelitian yang berbeda dilaporkan oleh Thomas et al., (1994) yang menunjukkan bahwa LCC dapat berpengaruh negatif terhadap pertumbuhan tanaman karet dibandingkan dengan tanpa vegetasi saat terjadi El Nino. Hal ini terjadi karena air lebih banyak terserap oleh Mucuna bracteata atau vegetasi lainnya. Dalam penelitian ini, tidak dijumpai El Nino (Tabel 1) sehingga pertumbuhan tanaman tidak ditentukan oleh adanya keterbatasan air. 


\section{Bobot Kering Legume Cover Crop dan Gulma}

Bobot kering LCC pada penelitian ini menunjukkan jumlah yang lebih besar dibandingkan dengan gulma alami baik pada perlakuan dengan maupun tanpa olah tanah. Pada perlakuan olah tanah, bobot kering pada LCC adalah $250,5 \mathrm{~g} / \mathrm{m}^{2}$, sedangkan gulma alami adalah $74,75 \mathrm{~g} / \mathrm{m}^{2}$. Sementara itu, bobot kering LCC pada perlakuan tanpa olah tanah adalah 290,5 g sedangkan gulma alami adalah 77,75 g. Hal ini terlihat bahwa Mucuna bracteata menghasilkan lebih banyak biomassa dibandingkan dengan gulma alami sehingga akan berkontribusi lebih besar untuk peningkatan bahan organik. Bahan organik juga merupakan salah satu faktor yang mempengaruhi pembentukan kemantapan agregat dan bobot isi tanah (Smucker, Park, Porner, \& Horn, 2007). Potensi serasah MB pada tahun pertama dapat mencapai $\pm 3,7$ ton kering (Nugroho, Istianto, Siagian, \& Karyudi, 2010).

\section{KESIMPULAN}

Perlakuan sistem pengolahan tanah pada penelitian ini tidak mengubah sifat fisik tanah di perkebunan karet. Disisi lain, vegetasi diantara gawangan (MB dan GA) mengubah indeks kemantapan agregat, bobot isi, dan porositas total tanah. Pada umur 26 BST, pertumbuhan tanaman karet tidak berbeda antar perlakuan olah tanah namun terdapat beda nyata antar perlakuan vegetasi di gawangan tanaman karet. Oleh karena itu, disarankan untuk menjaga vegetasi pada gawangan tanaman karet dengan Mucuna bracteata dan gulma alami namun tetap adanya perawatan agar tidak terjadi kompetisi hara dan air dengan tanaman karet. Berdasarkan pengukuran bobot kering LCC dan gulma, LCC menghasilkan lebih banyak biomassa sehingga akan berkontribusi lebih besar untuk peningkatan bahan organik.

\section{UCAPAN TERIMA KASIH}

Ucapan terima kasih disampaikan kepada Dr. Thomas Wijaya sebagai peneliti utama yang telah memberikan masukan dan saran kegiatan penelitian ini.

\section{DAFTAR PUSTAKA}

Attou, F., Bruand, A., \& Lebissonnais, Y. (1998). Effect of clay content and siltclay fabric on stability of artificial aggregates. European Journal of Soil Science, 49, 569-577. Doi :

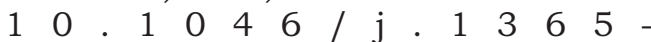
2389.1998.4940569.x

Busscher, W.J., \& Bauer, P.J. (2003). Soil strength, cotton root growth and lint yield in a shoutheastern USA coastal loamy sand. Soil and Tillage Research, 74 ( 2 ) , $151-159$. D o i: $10.1016 /$ j.still.2003.06.002

Bronick, C.J., \& Lal, R. (2005). Soil structure and management : review. Geoderma, $124(1-2), 3-22$. D o i : $10.1016 /$ j.geoderma.2004.03.005

Cammeraat, E., Beek, R.V., \& Kooijman, A. (2005). Vegetation succession and its consequences for slope stability in SE Spain. Plant and Soil, 278, 135-147. Doi : $10.1007 /$ s $11104-005-5893-1$

Fohrer, N., Berkenhagen, J., Hecker, J.B., \& Rudolph, A. (1999). Changing soil and surface conditions during rainfall single rainstorm/subsequents rainstorm. Catena, 37(3-4), 355-375. Doi : 10.1016/S0341-8162(99)000260

Grant, C.A., \& Lafond, G.P. (1993). The effects of tillage systems and crop sequences on soil bulk density and penetration resistance on a clay soil in southern saskatchewan. Canadian Journal Soil Science, 73(2), 223-232. Doi : $10.4141 /$ cjss93-024

Haynes, R.J., \& Beare, M.H. (1997). Influence of six crop species on aggregate stability and some labile organic matter fraction. Soil Biology and Biochemistry Journal, 29(11-12), 1647 - 1653. Doi : 10.1016/S00380717(97)00078-3

Hoorman, J.J. (2009). Using cover crops to improve soil and water quality. Fact sheet agriculture and natural resources. Ohio, US : The Ohio State University. 
Luttrell, D.H. (1963). The effect of tillage operations on bulk density and other physical properties of the soil (Retrospective Theses and Dissertation). Iowa State University, US.

Miller, P.R.E., \& Brinklemeyer, R.R. (2004). Soil carbon sequestration : Farm management practices can affect greenhouse gasess. Bozemen, US : Montana State University.

Nugroho, P.D., Istianto., Siagian, N., \& Karyudi. (2010). Pengaruh penanaman Mucuna bracteata terhadap status hara dan pertumbuhan tanaman karet belum menghasilkan. Jurnal Penelitian Karet, 28(2), 44-54.

Oost, K.V., Govers, G., \& Desmet, P. (2000). Evaluating the effects of changes in landscape structure on soil erosion by water and tillage. Landscape Ecology, $15(6), 577-589$. D o i: $10.1023 / \mathrm{A}: 1008198215674$

Osunbitan, J.A., Oyedele., D.J., \& Adekalu, K.O. (2005). Tillage effects on bulk density, hydraulic conductivity and strength of a loamy sand soil in Southwestern Nigeria. Soil and Tillage Research, 82(1), 57-64. Doi : 10.1016/j.still.2004.05.007

Poulenard, J., Podwojewski, P., Janeau, J-L., \& Collinet, J. (2001). Runoff and soil erosion under rainfall simulation of Andisol from the Ecuadorian Paramo : effect of tillage and burning. Catena, 45(3), 185-207. Doi : 10.1016/S03418162(01)00148-5

Plante, A.F., \& McGill, W.B. (2002). Soil aggregate dynamics and the retention of organic matter in laboratoryincubated soil with differing simulated tillage frequencies. Soil and Tillage Research, 66(1), 79 - 92. Doi : 10.1016/S0167-1987(02)00015-6
Rhoton, F.E., Shipotalo, M.J., \& Lindbo, D.L. (2002). Run off dan soil loss from midwestern and southeastern US silt loam soil as affected by tillage practice and soil organic matter content. Soil and Tillage Research, 66(1), 1-11. Doi : 10.1016/S0167-1987(02)00005-3

Rouquerol, J., Avnir, D., Fairbridge, C.W., Everett, D.H., Haynes, J.H., Pernicone, N., Ramsay, J.D.F., Sing, K.S.W., \& Unger, K.K. (1994). Recommendations for the charaterization of porous solids (technical report). Pure Appl. Chem, $66(8), 1739-1758$. Doi : $10.1351 /$ pac199466081739

Smucker, A., Park, E.J., Dorner, J., \& Horn, R. (2007). Soil micropore development and contribution to soluble carbon transport within macroaggrates. Vadoze Zone Journal, 6(2), 282-290. Doi : $10.2136 / v z j 2007.0031$

Stirzaker, R.J., Passioura, J.B., \& Wilms, Y. (1996). Soil structure and plant growth : Impact of bulk density and biopores. Plant and Soil, 185(1), 151-162. Doi : 10.1007 / BF02257571

Thomas., Lasmingsih, M., Junaidi, U., Wibawa, G., Amypalupy, K., \& Sihombing, H. (1994). Pengaruh kekeringan dan usaha mengatasinya pada tanaman karet. Warta Perkaretan, 13(2), 1-7 